\title{
Do bumper ads bump consumers?: An empirical research on YouTube video viewers
}

\author{
Ayda Sabuncuoğlu-i̇nanç; Ebru Gökaliler; Göker Gülay
}

How to cite this article:

Sabuncuoğlu-inanç, Ayda; Gökaliler, Ebru; Gülay, Göker (2020). “Do bumper ads bump consumers?: An empirical research on YouTube video viewers". El profesional de la información, v. 29, n. 1, e290114.

https://doi.org/10.3145/epi.2020.ene.14

Manuscript received on $12^{\text {th }}$ February 2019 Accepted on $26^{\text {th }}$ November 2019

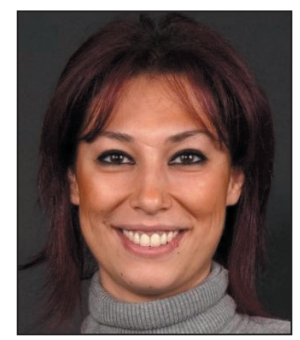

Ayda Sabuncuoğlu-ínanç https://orcid.org/0000-0003-4999-9663

Sakarya University

Faculty of Communication

Public Relations and Advertising Depart.

Esentepe Campus, M2, Serdivan,

Sakarya, Turkey

aydainanc@sakarya.edu.tr

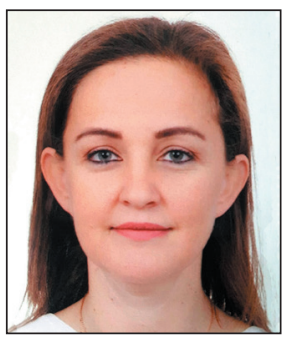

Ebru Gökaliler

https://orcid.org/0000-0002-4134-8447

Yasar University

Faculty of Communication

Public Relations and Advertising Depart.

Üniversite Caddesi, 37-39 Bornova,

Izmir, Turkey

ebru.gokaliler@yasar.edu.tr

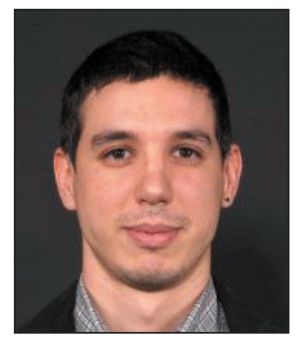

Göker Gülay $\bowtie$

https://orcid.org/0000-0003-1217-3091

Yasar University

Faculty of Communication

Public Relations and Advertising Depart.

Üniversite Caddesi, 37-39 Bornova,

Izmir, Turkey

goker.gulay@yasar.edu.tr

\begin{abstract}
YouTube, the most popular present-day online video platform, is also considered one of today's leading advertising media. There is an ongoing argument that YouTube measures and shares its own ad effectiveness. However, the consumer research results contradict with their measurements. The difficulty of measuring the performance of video ads on YouTube without YouTube's built-in data increases the debate about its effectiveness as an advertising environment and therefore makes it more important to collect data from consumers through empirical research. This study was carried out with YouTube viewers located in Turkey, whose population is among the most online video watching Internet users in the world, to uncover the determining attitudes and the factors affecting them in the effectiveness of bumper ads, which YouTube introduced in 2016 as 6-seconds unskippable ad videos. The acquired data were tested by correlation and regression analysis under a predicted model that could explain the attitudes towards the ad. According to findings; it has been shown that the attitudes towards bumper advertisements are significantly related to the factors such as entertainment, informativeness, credibility, irritation, frequency of exposure and advertising value. However, it was found that the participants did not develop a positive attitude towards these factors, and the bumper advertisements, along with them.
\end{abstract}

\section{Keywords}

Advertising attitudes; Advertising value; Bumper advertising; YouTube advertising; Digital video advertising; YouTube.

\section{Introduction}

With the increasing emergence of new digital advertising types, advertisers have been striving to monetize from these various types over the last years. Nowadays advertisers are giving more importance to digital video ads (DVA), because $47 \%$ of live streaming video viewers worldwide are streaming more live video compared to 2017 (IAB, 2018d, p. 11), and by 2019 global consumer internet video traffic will account for $80 \%$ of all the consumer internet traffic (Cisco, 2018). Advertisers, who take the consumption of mobile devices and the rise in the video viewing into account increased their 
investment in DVA recently. According to eMarketer's last research about DVA effectiveness (Verna; Clayton; Creamer, 2017, p. 2), DVA spending will grow from $\$ 15.42$ billion in 2018 to double-digit annual rates for at least the next four years, surpassing $\$ 22$ billion in 2021. DVA reaches consumer via social media platforms such as Facebook, Instagram, YouTube, Snapchat, and Twitter. YouTube that increased its registered users worldwide from 1.5 billion in June 2017 to 1.8 billion in March 2018 is now predicted to have 1.86 billion users in 2021 (Statista, 2018a; 2018b). It has become one of the biggest DVA platforms. eMarketer (Verna; Clayton; Creamer, 2017, p. 7) expects YouTube's net ad video revenues to reach $\$ 3.57$ billion in 2019, up from \$3.23 billion in 2018 .

Previously YouTube was just offering non-skippable DVAs to their clients along with its display, overlay ads. But suffering from 15-, 30-, or even 60-second pre-roII ads prompted so many back-button clicks that eventually YouTube had to add a skip button to their ads in 2009 (Chi, 2018). In 2011, YouTube sales director Bruce Daisley announced that just $30 \%$ of their skippable ads were actually skipped. After the announcement, some technology and social media sites stated that they were doubtful about the percentage which YouTube has an-

nounced (Fisher, 2011; Rick, 2011). The consumer research results on YouTube's video effects contradict with YouTube's announcements. A research by IPG Media $\operatorname{LAB}(2016$, pp. 9, 11) revealed that $65 \%$ of people skip DVA and skipping is an ingrained behavior for them. Also the data shows that $84 \%$ skip the DVAs when they are exposed to video ads on smartphones. Similarly, LaunchLeap determined that $59 \%$ of millennials only watch YouTube video ads until they are allowed to skip the ad (Kirkpatrick, 2017). From all these results, it can be seen that YouTube's skippable DVA data and consumer research data contain different views and interests.

It has been argued for a long time that YouTube is making its own measurements and sharing these measurements with ad buyers. According to The Wall Street Journal; YouTube says that it supports third party tracking but not in a common way. Instead of allowing third parties to directly pull data from their sites or mobile apps, YouTube receives tracking code from third parties and then modifies the code slightly. It also set up a different process to deliver data. Because of this process, ad buyers want more transparency into how third-party data is collected on Google's YouTube, and ideally more oversight over the process, since it helps them determine where and how to spend their video marketing money (Shields, 2016). While this controversy continued, Google announced that they are launching an ads measurement for YouTube on 2017 that called Ads Data Hub to help advertisers measure the value of their campaigns as ads are distributed over an ever-expanding number of devices. However, Google states that marketers can't extract any of the impression-level data from Ads Data Hub for privacy reasons. Also, Google explained that advertisers can give third-party measurement vendors, including comScore, DoubleVerify, Integral Ad Science and Nielsen, access to the system. But those vendors must still rely on Google's own data for measurement. It shows that Ads Data Hub was not enough for advertisers who have been pushing Google to lower their walls and support independent tracking for measurement and verification (Marvin, 2017).

In 2016, at Sundance, YouTube launched bumper video ads that are unskippable 6-second ad units as a solution to the skipping behavior of its users. Google (2016) announced that huge brands are using bumper ads to drive upper-funnel goals like ad recall and awareness and they are a cost-effective way to reach target audience. Furthermore, Google stated that they have tested over 300 bumper campaigns and found that 9 out of 10 drove a significant lift in ad recall. The brands can ensure their message is seen and heard with bumpers, although the ads are short in time, they're long in impact. Similarly, YouTube chief business officer Robert Kyncl also said that (Verna; Clayton; Creamer, 2017, p. 7) YouTube saw a $70 \%$ increase in the number of advertisers that ran 6-second ads on the platform in 2017 and one-third of YouTube advertisers now use the bumpers.

The unilateral disclosure of YouTube's own data about the bumper ads, and the presentation of this data to the ad buyers allow ad buyers to see the effect of these ads in a biased way. Since consumer attitudes play a major role in predicting advertising effectiveness (Mehta, 2000) and they have a significant effect on the interest in buying online (Aqsa; Kartini, 2015, p. 234) then it is of utmost importance to predict the attitudes of the consumers towards bumper ads. If ad buyers want to use the bumper ads in an efficient way, they have to know the consumers' attitudes towards bumper ads. This makes the discovery of the attitudes of users towards bumper advertisements and the variables that make up these attitudes an academic interest. In the field related to literature and in academic studies on digital advertising, it is seen that the factors that constitute attitudes towards digital advertisements are examined by using various models. However, studies on attitudes towards bumper advertisements are not yet sufficient. Using a conceptual model, this study is aimed at revealing the
The unilateral disclosure of YouTube's own data about the bumper ads, and the presentation of this data to the ad buyers allow ad buyers to see the effect of these ads in a biased way 
level of attitude towards bumper advertisements and the variables that constitute these attitudes. Within the scope of this aim, a research was prepared within the framework of a model which is foreseen explain the attitudes towards bumper advertisements. The findings of the survey about internet users in Turkey, which has one of the highest rates of online video viewing in the world, were examined.

\section{Bumper ads as a new model for digital video ads (DVAs)}

The rapid development of internet technology and its easy integration into individuals' daily lives had led to the development of digital advertising in a short time. The Web 2.0 concept, which began to be used in 2004, represents the general name of second-generation internet services, where internet users are no longer simply consuming, but also producing information at the same time. The interactive nature of Web 2.0, including the user, has led to the inclusion of interactive web pages on the Internet with the development of Internet; digital advertising has also started to develop. As a result of the developments in the digital advertising that happened in the last 20 years, digital advertising is divided into three groups; namely content agnostic advertising (random placing advertisements), contextual advertising (placing relevant advertisements based on context) and semantic advertising (placing advertisements based on the semantic analysis) (Cheng et al., 2017, p. 1172).

Founded in 2005 and bought by Google in 2006, YouTube's easy and fast video sharing experience encourages users to share videos, and makes the platform one of the most preferred social networks in a short time. Due to the TV shows and movies that have been watched by a wide range of people on the internet in recent years, digital video advertising, whose main purpose is to attract more of the potential customers has become a huge business opportunity with a rapid and sustainable development (Wang et al., 2018, p. 40). In this context, DVA is important for influencing consumers in terms of content and advertising messages. The fact that consumers are part of the internet, often producing content and watching videos, has increased the variety of digital advertisements in these medium. DVA is defined as the integration of video ads into advertisements or regular online contents (Turban et al., 2017, p. 278). According to the IAB (2008, p. 3) definition, DVA is a type of digital ad that has live, archived, or downloadable content that takes place before, during, or after various contents (Brown; Jones; Wang, 2016, p. 241). In this context, DVA, which has advanced with Google AdSense, has strengthened its algorithm with Google's purchase of YouTube. YouTube DVA has become an important channel for being able to transfer the advertising message to the right audience. The most preferred channel for DVA investments is video advertising seen in video with $26 \%$ (IAB, 2018c, p. 41). Even though the types of digital ads are considered to fall in certain categories, YouTube's DVA diversity constitutes the basic categories of this advertising model. While ads called display ads, sponsors cards, and overlays ads are taking place as images within the video; video ads, skippable video ads, non-skippable video ads, and bumper ads are video advertisements. First, DVA in-stream video advertisings began as short video ads, such as television commercials. In 2010, YouTube developed a DVA called "TrueView in stream advertising," which allowed it to jump after the first 5 seconds of the ad. This type of ad was developed specifically to increase the metric based effect of ad content on search terms (Pashkevich et al., 2012, pp. 451-457). Along with changing consumer needs and attributes, advertising is also in the process of rapid change. While an average person's "attention span" was 12 seconds in 2000 (Landau, 2015, p. 44), according to the report conducted by Microsoft Corp. and published by Time magazine in 2015, the "attention span" has now fallen to 8 seconds (Abdow, 2018, p. 34). With the decrease of the "attention span" of consumers every day, the necessity of revision of advertising periods and the emergence of new advertising types arise. In 2016, YouTube announced a new 6-second non-skippable CPM-based bumper ad that could be featured on videos. YouTube aimed to encourage advertisers by bumper ad type about the value and power of stories created in short form on mobile (Caufield, 2017). Then in 2017, Facebook and Twitter also announced "bumper" ads as an ad type to be placed on their own sites (IAB, 2018a, p. 8). For advertisers and marketers who are looking for new techniques to communicate messages and attract attention of the consumer, the 6-second bumper advertising quickly became an important type of advertising. According to the DVA study conducted by Adweek and GumGum in 2018, it was determined that marketing experts evaluated bumper advertisements as the best DVA. According to the same research, $27 \%$ of the bumper advertisements were very effective and 54\% effective (Fleck, 2018). In another study conducted about 6-second ads in 2018, brand recall is higher in bumper ads than 15-second and 30-second ads, and viewers are generally more positive about bumper advertising (Marci, 2018). Bumper advertisements, which is soon became a standard ad format for digital media, is today the preferred type of advertising for overcoming consumers' "ad avoidance" (Sloane, 2017). In addition, brands prefer 6-second short ads instead of long ads; because consumers are bothered by them and their tolerance for ads are reduced every day (Shutterstock, 2017). In addition to this digital medium, 6-second short advertisements in traditional TV programs have been implemented in 3 different strategies as

- "premium focus / reach build,

- multi-airing cable-frequency build, and

- hybrid strategy." 
Global brands like Toyota, Pepsi and Duracell prefer these ads on TV channels like Fox, NBC, TLC, CNN and Discovery Channel (Donato; Schiffman, 2018, p. 10).

\section{Consumer attitudes toward DVAs}

Researches conducted with the aim of examining consumers' attitudes towards advertising reveal that consumers' attitudes towards traditional advertisements are in general negative (Zanot, 1984). Moreover, the reason for this outcome is that consumers find the information contained in advertisements unnecessary and even irritating. According to some researches, consumers have developed more positive attitudes especially towards internet-based advertising (Schlosser; Shavitt; Kanfer, 1999). The reason for this is that these advertisements, by targeting consumers, provide them with the information they need and are more entertaining (Xu; Li, 2014, p. 3). According to Ducoffe (1996), and Brackett and Carr (2001), individuals' beliefs about ads lie on the basis of attitudes toward advertising, which is defined by Mackenzie and Lutz (1989, p. 54) as

"a learned tendency to respond positively or negatively to advertising in a steady manner."

There are a number of studies aimed at determining consumer attitudes towards social media ads, including "DVAs", one of the most important types of internet advertising today. According to the results of the research conducted by Akar and Topçu (2011, pp. 53-54); individuals who have clicked on social media ad messages at least once have more positive attitudes towards social media advertising and marketing activities than those who have never clicked. In addition to these results, research results show that as the frequency of Facebook usage of individuals increase, the attitudes towards social media advertising and marketing activities are more positive. Cheng et al. (2009, p. 516) addressed three different attitudes; informative, entertaining and irritating, in the research they conducted in order to determine consumers' attitudes towards social media advertising, and revealed that consumers have seen their social media ads as informative, annoying and entertaining with their rankings. According to Moon's study of attitudes toward YouTube video ads (2014, p. 28), the consumers who watched the advertising in high video quality held significantly more favorable attitudes toward the DVAs than those who watched the same advertising in low quality. Another research shows that (Li; Lo, 2015, p. 216); in-stream YouTube video ads interrupt consumers' video viewing experience and such interruption is likely to generate feelings of intrusiveness.

Additionally Lee and Lee's (2011, p. 622) research data revealed that the more the participants believed watching online video ads would entertain them, the more positive were their attitudes toward the ads. Similarly Gunawan (2015, p. 420) found that for positive consumer attitudes DVAs must focus on making emotional impact. There are also some studies that show whether attitudes towards internet-based advertising vary according to demographic factors such as age, gender, and education. Schlosser, Shavitt and Kanfer (1999) found that younger consumers have more positive attitudes towards advertising, in comparison to other age groups. Similarly, according to the research results of Chu and Kim in 2011, university students and young consumers are more positive towards social media ads than other age groups (Gaber; Wright, 2014, p. 56). Several studies have examined the relationship between gender differences and attitudes towards advertising. Most of the past research suggests that male consumers, unlike female ones, tend to have more positive beliefs and attitudes towards advertising including specific types of advertising, for example web advertising, and positive reactions to advertisements as well (retrieved from Milaković; Mihić, 2015, p. 413). According to the research results of Wolin and Korgaonkar (2003); men have more positive attitudes towards internet based advertising than women. However, if ads are irritating, positive attitudes are affected negatively (Cheng et al., 2009, p. 507). There is an important connection between the level of education of a consumer and his response to the advertising message, and the level of education influences the perception and understanding of the content of the message and the choice of advertising media. According to Shavitt, Lowrey and Haefner (1998); less-educated people generally report more positive attitudes towards advertising and the enjoyment they have from the ad is greater than more educated people.

\section{Research model and hypotheses}

In his researches aimed at revealing attitudes towards internet-based advertising by consumers, Ducoffe (1996) defined antecedent factors, which help consumers develop their attitudes, as informativeness, entertainment and irritation, and formed the attitude model for advertising with these factors included in message content. Brackett and Carr (2001) also add to the reliability of these models by developing the model variables. Since attitudes toward advertising in general can explain individuals' attitude toward online

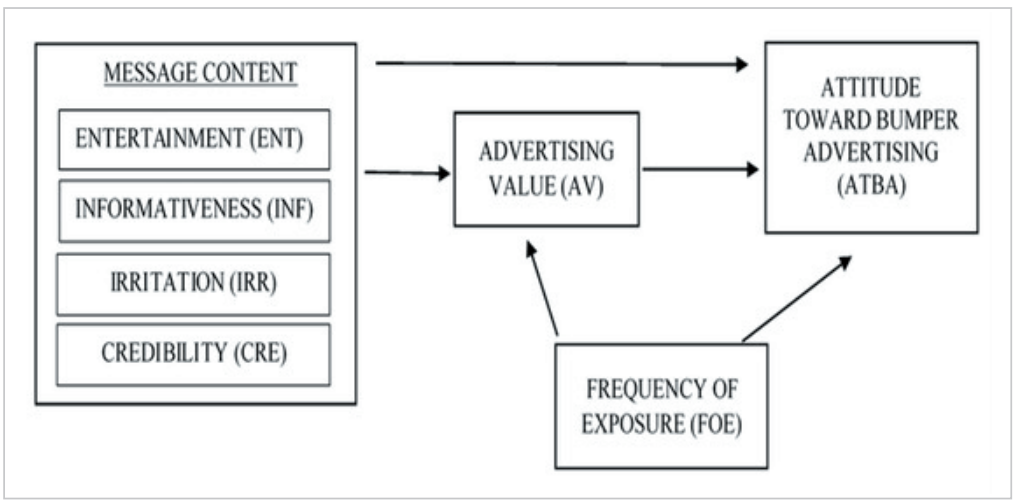

Figure 1. Conceptual model (developed from Brackett \& Carr, 2001) 
advertising to a large extent (Souiden; Chtourou; Korai, 2017, p. 210) this study strives to determine the attitudes towards bumper advertising.

In the light of all these data, the conceptual model used to determine consumers' attitudes towards bumper advertisements is given in Figure 1.

\subsection{Advertising value and attitude toward bumper advertising}

Ducoffe's 'Advertising value model' is mostly used for explaining consumer attitudes toward advertising. In his model Ducoffe defined advertising value as

"a subjective evaluation of the relative worth or utility of advertising to consumers" (Ducoffe, 1995, p. 1).

In his model (1996), Ducoffe states that web advertising value has a significant influence on attitude towards web ads. In the light of all these data, the following hypothesis is proposed in the study;

$\mathrm{H}_{1}$ : A high advertising value is "positively" correlated with a positive attitude towards bumper ads.

\subsection{Entertainment - advertising value and attitude toward bumper advertising}

Ducoffe $(1995 ; 1996)$ states that entertainment is one of the major antecedents that contributes to consumers' evaluations of advertising values and attitudes towards the web ads. Entertaining, which can be defined as the level of enjoyment contained within the advertising message, often includes features such as humor, music and play, which also affect the consumer's attention to remain in the message. Especially nowadays, advertising messages presented via mobile applications and internet are highly entertaining (Le; Nguyen, 2014, pp. 91-92), and research shows that consumers develop positive attitudes about advertising as they enjoy it and find it entertaining (Bauer et al., 2005, p. 188; Tsang; Ho; Liang, 2004; Zernigah; Sohail, 2012, p. 649). The studies of Tsang, Ho and Liang (2004, pp. 67, 71) have shown that the most important factor that has helped consumers to develop positive attitudes towards advertisements has been entertainment, ahead of other factors; credibility, irritation and informativeness. The following hypotheses have been proposed in the framework of this information;

$\mathrm{H}_{2 \mathrm{a}}$ : A high entertainment factor of an advertising message is positively correlated with a 'positive' attitude towards advertising via bumper ads.

$\mathrm{H}_{2 \mathrm{~b}}$ : A high entertainment factor of an advertising message is positively correlated with a high advertising value.

\subsection{Informativeness - advertising value and attitude toward bumper advertising}

Ducoffe $(1995,1996)$ states that informativeness is one of the factors contributing to consumers' evaluations of advertising values and attitudes towards the web ads. Ducoffe defines informativeness as the ability of advertisers to inform buyers about product alternatives and to provide them with the most satisfying buying behavior. Shown as the greatest income consumers can obtain from advertisements, information can determine the direction of consumers' attitudes towards advertising. In other words, how positive the consumer views the ads is in direct ratio to how much the advertising responds to the consumers' information needs (Saadeghvaziri; Khodadad-Hosseini, 2011, p. 397). Internet-based advertisements can be considered more informative than other advertisements because they provide consumers instant access to up-to-date information and different types of information, and they can present information about new products and services instantly. The informativeness factor has a direct impact on the attitudes that consumers have developed for internet-based advertising. This effect is due to providing information to consumers and helping them make purchasing decisions (Tsang; Ho; Liang, 2004). The more informative the advertising message is, the more positive the attitude is (Brackett; Carr, 2001, pp. 30-31, Zernigah; Sohail, 2012, p. 656). According to the findings of Zernigah and Sohail (2012, p. 657); the most important factor that has enabled consumers develop positive attitudes towards advertisements has been informativeness, taking precedence over other factors; reliability takes second place while entertaining takes last place. Therefore, the following hypotheses are suggested in the study;

$\mathrm{H}_{3 a}$ High informativeness of an advertising message is positively correlated with a 'positive' attitude toward advertising via bumper ads.

$\mathrm{H}_{3 \mathrm{~b}}$ High informativeness of an advertising message is positively correlated with a high advertising value.

\subsection{Irritation - advertising value and attitude toward bumper advertising}

Ducoffe $(1995 ; 1996)$ states that irritation is one of the antecedent factors contributing to consumers' evaluations of advertising values and attitudes towards the web ads. Ducoffe (1996, p. 22) describes irritation as an emotional state that occurs when advertising messages are offending, irritating, disturbing, confusing, and manipulative; while Brackett and Carr (2001) argue that this factor arises when consumers' intelligence is offended, and when they are exposed to messages in irritating patterns and frequencies. Although internet-based ads are as irritating as those exposed in traditional medium (Le; Nguyen, 2014, p. 92), Tsang, Ho and Liang's study showed that, if advertising messages are defined by consumers as irritating, their attitudes towards advertising are negative, and there is a negative relationship between them. Given this data, the following hypotheses are proposed in the study; 
$\mathrm{H}_{4 \mathrm{a}}$ : Irritation of an advertising message is negatively correlated with a 'positive' attitude towards bumper ads.

$\mathrm{H}_{4 b}$ : Irritation of an advertising message is negatively correlated with a high advertising value.

\subsection{Credibility and attitude toward bumper advertising}

According to Brackett and Carr (2001), reliability is the most important and critical factor affecting consumer attitudes and advertising value for internet based advertising. It is defined by Mackenzie and Lutz $(1989$, p. 51) as a cognitive experience that comes out as a result of the perception that either the advertisement or the commitments of the brand in it are not real, credible or fair. According to Haq (2009, p. 214), reliability can be the source of the message, not just the advertising message that affects it, and in this context, internet-based ads are less reliable than those communicated through traditional channels. Research by Kelly, Kerr and Drennan (2010) also supports Haq (2009) and shows that if young people do not find social media ads as trustworthy, they get away from them and ignore them. The studies of Brackett and Carr (2001), Zernigah and Sohail (2012), and Tsang, Ho and Liang (2004) have shown that there is a positive relationship between the reliability factor and the attitude toward advertising, that the more the consumers find advertisement messages reliable, the more their attitudes towards those messages get positive. Given this data, the following hypotheses are proposed in the study;

$\mathrm{H}_{5 \mathrm{a}}$ : High credibility of an advertising message is positively correlated with 'positive' attitude toward bumper ads.

$\mathrm{H}_{5 b}$ : High credibility of an advertising message is positively correlated with a high advertising value.

\subsection{Frequency of exposure - advertising value and attitude toward bumper advertising}

Advertising frequency influences consumers' attitude towards advertising (Chih-Chung et al., 2012, p. 358). As the quantity of ad messages rises, the attitude towards the advertising worsens (Haghirian; Madlberger, 2005). According to Haghirian and Dickinger, the number of advertising messages received via mobile devices is an important factor that influences the advertising value for the consumer (Haghirian; Madlberger, 2005). Since there is no empirical evidence on the relationship between web advertising frequency and advertising value, this research has formed these hypotheses based on the above findings.

$\mathrm{H}_{6 a}$ : Frequency of exposure of an advertising message is negatively correlated with a 'positive' attitude toward bumper ads.

$\mathrm{H}_{6 \mathrm{~b}}$ : Frequency of exposure of an advertising message is negatively correlated with a high advertising value.

\section{Research design}

The main objective of this research is to uncover factors determining the attitudes of internet users in Turkey towards bumper ads. According to We are social 2018 data, there are 54.33 million active internet users in Turkey, of which 51 miIlion are active social media users (Kemp, 2018). According to the January 2018 data, internet users watch online video, 95\% in Turkey, and rank $2^{\text {nd }}$ in the world with this ratio (Statista, 2018c). Turkish internet users spend 7 hours 9 minutes a day on the internet, and spend 2 hours 48 minutes on social media (We are social, 2018). The most actively used social media platform in Turkey is YouTube with 55\% (Kemp, 2018). The 18-49 age group prefer YouTube channels to traditional TV channels (O'Neil-Hart; Blumenstein, 2016; Hamedy, 2016). To reach active YouTube viewers in study's framework, participants aged between 18 and 49 were targeted. However, reaching to the right audience who are exposed to bumper ads and consuming YouTube content extensively was challenging for researchers due to the low response rates to online surveys. Consequently, the sample of the study was formed by snowball sampling

Reaching to the right audience who are exposed to bumper ads and consuming YouTube content extensively was challenging for researchers due to the low response rates to online surveys method, which is a non-probability sampling technique and often employed when no sampling frame can be constructed as in this study, due to the structure of the study population. Snowball sampling is based on a referral approach where a small number of participants with specific characteristics recruit other participants with same characteristics from their networks or community. Thus, it is considered as a suitable method in studies lend on credibility to research, due to the fact that study participants would likely know other people in the same situation as themselves and help them to overcome fear and mistrust, which, in turn, ensures access. Based on this rationale, snowball sampling was chosen as the main method for this research.

\subsection{Sampling design and data collection}

In the first step, a small group representing the research sample was reached and invited to participate in the survey. About one third of the participants received the questionnaire directly from the researchers (primary participation rate is $32 \%, n=271$ ) In the second stage, the study team gently asked primary participants whether they would be willing to pass the survey form they just completed to others who may be interested of eligible. Rest of the participants with similarities in terms of their demographic characteristics and habits of consuming internet video, received the survey invitation indirectly via primary participants from a web addressee (secondary participation), if they are approved by the 
primary participant for possible inclusion. To defense against the lack of "sample diversity" in the study and ensure that the initial set of respondents is sufficiently varied researchers strategically began the sample with seed that are diverse as possible in terms of demographic and socio-economic variables, which was a necessary condition for valid research findings. By this means, the sample was created by enlarging with the effect of snowball, which increased the sample size and its representativeness (Bailey, 1987, p. 96).

The questionnaire consists of three parts. In the first group, participants were asked about the frequency of YouTube exposure and exposure to YouTube ads, measured by a 5-point Likert rating (Always, Very frequently, Occasionally, Rarely, Very rarely, Never). In the second part of the questionnaire, in order to determine the effect of informativeness, entertainment, irritation and credibility variables on consumer attitudes towards bumper advertisements, scales consisting of 19 statements were taken from the studies of Soh, Reid and Whitehill-King in 2009, named "Measuring trust in advertising: Development and validation of the adtrust", and Cheng et al. in 2009 named "Consumer attitudes and interactive digital advertising". For the attitude variable, three statements were taken from the scale of Xu and Li's (2014) work "Advertising in new media: Exploring adoption of location-based mobile application advertising". The three statements of Advertising Value were taken from the work of Ducoffe (1995), "How Consumers Assess the Value of advertising". In the third group, questions about demographic characteristics were included. A visualization was prepared to remind participants what type of advertising is "bumper advertising", which was a new internet advertising campaign. There were 34 items in the questionnaire, 25 of which belonged to the scales used. Statements in the questionnaire were prepared with Likert rating of 5 (5-Strongly agree, 4-Agree, 3-Undecided, 2-Disagree, 1-Strongly disagree). Please refer to Table 1 for further details on the measures applied.

Once created, the survey was transferred to Google Forms https://docs.google.com/forms

The questionnaire was distributed in social networking sites and forums between July 5, 2018 and July 27, 2018. Participation was voluntary and the survey completion process took approximately $10 \mathrm{~min}$. The study received 847 responses. As all participants completed the full survey, the completion rate was $100 \%$. There was not any invalid questionnaire and all 847 questionnaires were usable. Data were analyzed using SPSS 22.0. In some cases, some scale expressions were encoded in reverse.

Table 1. Properties of purified measures

\begin{tabular}{|l|c|c|c|c|}
\hline \multicolumn{1}{|c|}{ Measures } & Items & Mean & Std. deviation & Variance \\
\hline Message content (MC) & & & & .83 \\
\hline EN & 5 & 1.96 & 1.005 & .779 \\
\hline INF & 6 & 2.75 & .868 & .011 \\
\hline IRR & 4 & 3.59 & .914 & .754 \\
\hline CRE & 4 & 2.44 & .880 & .836 \\
\hline AV & 3 & 2.72 & .989 & .774 \\
\hline ATBA & 3 & 2.24 & .714 & .978 \\
\hline FOE & 1 & 4.40 & .851 \\
\hline
\end{tabular}

\section{Findings}

Demographic data showed that males made up 37.4 percent of the sample and 94.6 percent of respondents were 18 to 49 years old. The vast majority of participants were undergraduate $(61.9 \%)$ and graduate $(30.2 \%)$ and had middle to upper middle income level (83.9\%). Compared with a representative sample of the Turkish general public, our snowball sample is younger, and highly educated. Of these participants, 43.3\% rated watching YouTube videos "frequently" and

Table 2. Results of hypotheses tests

\begin{tabular}{|l|c|c|}
\hline $\mathrm{H}_{1}(\mathrm{AV})$ & & $.863^{* *}$ \\
\hline $\mathrm{H}_{2 \mathrm{a}}$ and $\mathrm{H}_{2 b}:(\mathrm{ENT})$ & $.640^{* *}$ & $.563^{* *}$ \\
\hline $\mathrm{H}_{3 \mathrm{a}}$ and $\mathrm{H}_{3 \mathrm{~b}}:(\mathrm{INF})$ & $.449^{* *}$ & $.583^{* *}$ \\
\hline $\mathrm{H}_{4 \mathrm{a}}$ and $\mathrm{H}_{4 \mathrm{~b}}:(\mathrm{IRR})$ & $-.301^{* *}$ & $-.394^{* *}$ \\
\hline $\mathrm{H}_{5 \mathrm{a}}$ and $\mathrm{H}_{5 \mathrm{~b}}:(\mathrm{CRE})$ & $.410^{* *}$ & $.515^{* *}$ \\
\hline $\mathrm{H}_{6 \mathrm{a}}$ and $\mathrm{H}_{6 \mathrm{~b}}:(\mathrm{FOE})$ & $-108^{*}$ & $-133^{* *}$ \\
\hline${ }^{*} \mathrm{p}<.05, * * \mathrm{p}<.01$ & \multicolumn{2}{|l}{} \\
\hline
\end{tabular}

$35.6 \%$ "occasional" when one day duration was consi-

dered. Nearly all of the participants (98.8\%) stated that they were exposed to watching YouTube videos and rated their frequency as "always" at 49\% and "often" at 44.6\%. 97.8\% of respondents preferred to skip a YouTube ad, if possible.

The results of the hypothesis test are given in Table 2. Accordingly, it was found that all the independent variables (ENT, INF, IRR, and CRE) that determined the message content and the AV and ATBA dependent variables were significantly correlated. Given this data, it is seen that as the levels of informativeness $(r=.449, p<.01)$, entertainment $(r=.640, p<.01)$ and credibility $(r=.410, p<.01)$ were increased, the value assigned to advertisement also increased positively. However, the increase in the incidence of irritation $(r=-.301, p<.01)$ and exposure to advertising $(r=-108, p<.05)$ affected 
this value negatively. Likewise, significant correlations between ATBA and ENT $(r=.563, p<.01)$, INF $(r=.583$, $p<.01)$, IRR $(r=-.394, p<.01)$, CRE $(r=-.515, p<.01)$, and FOE variables were also determined.

When we look at the relationship between $\mathrm{AV}$ and ATBA, it is seen that there is a strong correlation ( $r=$ $.863, p<.01$ ) between these two variables in the positive direction. This shows that as the value of advertising rises, the attitude toward bumper advertisements is also positively affected.

Multiple regression analysis was conducted to investigate the relationship between the attitude towards bumper advertisements, which was the dependent variable in the model, and the independent variables correlated with each other. The assumption of normal distribution and linearity, which are assumptions of regression analysis, were fulfilled.

A multiple linear regression was calculated to predict ATBA based on CRE, INF, ENT, IRR, FOE and AV (Table 3). A significant regression equation was found $[F(6.390)=270.271 \mathrm{p}<.000]$, with a R2 of .806. Participants' predicted ATBA is equal to $.164+.023$ (CRE) +.161 (INF) +.116 (INF) +.790 (AV) -.084 (IRR), -.043 (FOE). All of which were significant predictors of attitude towards bumper ads.

\section{Discussion and conclusion}

\subsection{Antecedent factors of attitudes towards bumper ads and ad value}

This study attempted to investigate antecedent factors of consumer attitudes toward bumper ads. According to the findings obtained from the research, the $\mathrm{H}_{1}$ hypothesis was supported and a positive and significant correlation was found between the advertising value and the attitude toward the bumper ads. The results of the research support Ducoffe's data in 1996, and it was seen that bumper advertising value had a significant influence on attitude toward bumper ads.

According to the findings obtained from the research; $\mathrm{H}_{2 \mathrm{a}}$ was supported and there was a positive and significant correlation between advertisements entertainment value and consumer attitudes. According to this, consumer attitudes towards these advertisements were also positively affected as the entertainment value of the bumper advertisements increases. The results of this study are in parallel with Le and Nguyen (2014), Bauer et al. (2005), Tsang, Ho and Liang (2004), and Zernigah and Sohail's (2012) research findings. In this context, it can be said that the bumper advertisements' quality of being entertaining is an important factor on consumer attitudes towards these advertisements. According to the findings obtained from the research, $\mathrm{H}_{2 \mathrm{~b}}$ was supported and there was a positive and significant correlation between the entertainment value of the advertisement message and the advertising value. According to this, as the entertainment level of the bumper advertisements increases, the advertising value of the consumer is also affected positively. The results of this study are in line with the findings of Ducoffe $(1995 ; 1996)$ in the literature. In this context, it can be argued that the entertainment value that exists in bumper advertisements contributes to the consumers' evaluations about the advertising value.

According to the findings obtained in the study, $\mathrm{H}_{3 a}$ was supported and there was a positive and significant correlation between informativeness and attitudes. According to this, consumer attitudes towards these advertisements were also positively affected as the level of informativeness of the bumper advertisements increases. These results are parallel to the findings of Brackett and Carr (2001), Zernigah and Sohail (2012) and Tsang, Ho and Liang (2004) in the literature. In this context, it can be said that informativeness has a significant influence on attitudes towards bumper advertisements.

According to the findings of the advertisement message obtained from the research, $\mathrm{H}_{3 \mathrm{~b}}$ is supported and there is a positive and significant correlation between the informational value of the advertisement message and the advertising value. According to this, as the level of informativeness of the bumper advertisements increases, the advertising value of the consumer is also affected positively. The results of this study are parallel to the findings of Ducoffe $(1995 ; 1996)$. In this context, the information available in bumper advertisements can contribute to consumers' evaluations of advertising values.

The survey results show that $\mathrm{H}_{4 a}$ is supported. A negative and significant correlation was found between the irritation value of the advertising message and the positive attitudes towards advertisements. According to this, consumer attitudes
As the level of informativeness of the bumper advertisements increases, the advertising value of the consumer is also affected positively 
towards these advertisements are adversely affected as the level of annoyance of the bumper advertisements increases. It is seen that these results are in parallel with the results of Brackett and Carr (2001), Le and Nguyen (2014) and Tsang, Ho and Liang (2004) in the literature. According to the findings obtained from the research, $\mathrm{H}_{4 \mathrm{~b}}$ was accepted and there was a negative and significant correlation between the annoyance level of the advertisement message and the advertising value. According to this, as the annoyance level of the bumper advertisements increases, the advertising value is affected negatively. The results of this study are in line with the findings of Ducoffe (1995; 1996) in the literature. In this context, the annoyance level of bumper advertisements can be said to contribute to consumers' evaluations of advertising values.

According to the findings obtained in the study, $\mathrm{H}_{5 \mathrm{a}}$ was accepted and a positive and significant correlation was found between reliability and attitudes. According to this, consumer attitudes towards these advertisements are also positively affected as the level of reliability of the advertisements increases. These findings are directly related to the results of Brackett and Carr (2001), Kelly, Kerr and Drennan (2010), Haq (2009), Zernigah and Sohail (2012) and Tsang, Ho and Liang (2004) in the literature. In addition, a positive and significant relationship was found between the reliability of the bumper advertisements and the advertising value in the study, and $\mathrm{H}_{5 b}$ was supported in this context. As the credibility of the bumper ads increases, the advertising value is also positively affected. These findings are in line with the results of the research by Brackett and Carr (2001) in the literature. In this context, the reliability of bumper advertisements can be said to contribute to consumers' evaluations of advertising values.

\subsection{The importance of frequency on attitudes towards bumper ads and ad value}

The $\mathrm{H}_{6 \mathrm{a}}$ hypothesis was supported according to the data obtained from the study. A negative correlation between advertising exposure frequency and a positive attitude for bumper advertisements was found. According to research data, as the frequency of exposure to bumper advertisements increases, the positive attitude towards these advertisements also decreases. In this context, as the frequency of exposure to the advertisement increases, consumers' discomfort level increases and the level of positive attitude for advertising decreases. This data is similar to the findings in the literature (Chih-Chung et al., 2012, p. 358; Haghirian; Madlberger, 2005; Haghirian; Dickinger). The $\mathrm{H}_{6 \mathrm{~b}}$ hypothesis is also supported. Negative correlations were found between the advertising value and the advertising exposure frequency. These findings are parallel to the findings in the literature.

\subsection{The role of demographic variables on attitudes towards bumper ads and ad value}

According to research findings, there was no significant correlation between the age and the education level of participants and attitudes towards bumper ads. Although findings in the literature indicate a relationship between age and attitudes towards advertising (Schlosser et al., 1999; Chu; Kim, 2011; Gaber; Wright, 2014, p. 56), the data obtained are not parallel to these findings. In parallel, there was no correlation between AV and age variables. The findings of Ducoffe (1996) are not parallel to the findings obtained. Although Ducoffe has established a relationship between the advertising value of internet advertising and age, this relationship is not found in the data obtained for bumper advertisements.

According to the results of $T$ test, ATBA $(P=588)$ and AV $(P=499)$ values did not differ according to sex. This finding differs from the findings of Milaković and Mihić (2015, p. 413), Wolin and Korgaonkar (2003); Cheng et al. (2009, p. 507), which takes place in the literature.
There was no significant correlation between the age and the education level of participants and attitudes towards bumper ads

Participants did not evaluate the bumper advertisements as entertaining $(M=1.96, S D=.883)$, informative $(M=2.75$, $\mathrm{SD}=1.005)$ or reliable $(\mathrm{M}=2.44, \mathrm{SD}=.914)$. It can also be concluded that participants were more likely to find bumper ads annoying $(M=3.59, S D=.868)$. In parallel, the advertising value variable, which is the determinant of the attitude toward bumper ads, shows that participants did not find the bumper advertisements worthwhile $(M=2.72, S D=.880)$. It can be said that the negative attitudes of participants to bumper ads ( $M=2.24, S D=.989)$ stem from bumper ads' not being informative, fun, reliable or worthwhile. The results of the multiple linear regression test and the hypothesis test, which reveal the relationship between the variables in the model, also support these findings. Looking at the parameters of the model's explanatory level $\left(R^{2}: 803\right)$, it can be said that the participants can explain their attitudes towards the bumper advertisements at a high level.

As previously stated, the goal of this research was to reveal the level of attitude towards bumper ads, and the variables that constitute it. Clearly, this goal has been achieved as reflected above. It is a fact that YouTube makes its own metrics, and delivers these metrics to "ad buyers", offering them their own video ads as very profitable and successful solutions, and "ad buyers" are not satisfied with this and expect more transparency from YouTube. Consumer research on YouTube video ads shows that YouTube data is unilateral and manipulative. The ability of ad buyers to effectively advertise is largely dependent on the research results of consumers. Since consumer attitudes play a major role in predicting advertising effec- 
tiveness (Mehta, 2000) and advertising value has a significant influence on attitude towards web ads, this study is important for determining the attitudes of ad buyers towards bumper ads, and their advertising value, and showing to ad buyers how bumper ads can become more effective. The research shows that, without demographic differences, consumers do not find bumper advertisements entertaining, informative or trustworthy, which affects their attitudes. The research data suggest that the frequency of exposure to the bumper advertisements should be correctly regulated in order to increase the positive attitude towards bumper advertisements. It may be argued that, in this framework, YouTube's adoption of an imaging model that will make the frequency of exposure to bumper advertisements is more reasonable for viewers. Also, brands will not disturb the consumer by differentiating the advertising content and provide them with more informative, entertaining and reliable content that will increase the positive attitude towards the relevant ads.

\section{Limitations and future research directions}

The study had several limitations. Choosing YouTube as the platform avoids the possibility of representing user experiences and perceptions with other multifarious digital video websites. There are many video sites using bumper advertising and the advertisements used may have different underlying principles. Further studies covering other video advertising media should be undertaken like Facebook, Google. In addition, the narrowness of the demographic qualities of the participants, and that the participants are chosen from Turkey is another limitation. In this context, it is important to continue the validation of the model by examining the factors that determine attitudes towards video ads in future studies on groups with different demographic and cultural backgrounds. In this study, the attitude towards bumper advertisements in the consumer dimension was examined, and the opinions of the brands about the consumer perceptions after the advertisement and the opinions about the brand were not included. In future studies, how consumers' opinions differ before and after an advertisement can be researched by making them watch bumper advertisements of a certain brand. Moreover, testing different metrics to analyze the effectiveness of bumper ads might be an aim for further studies. Considering different campaign objectives in advertising such as impact, positioning, brand or product awareness would require different metrics to be tested. In this respect, this study should be considered as a basis for further studies, due to the fact that it approaches the issue in terms of customers' positive attitudes only.

\section{References}

Abdow, Michelle (2018). "Get their attention, and you needn't worry about attention span”. BusinessWest, January 9. https://businesswest.com/blog/get-their-attention-and-you-neednt-worry-about-attention-span

Akar, Erkan; Topçu, Birol (2011). “An Examination of the factors influencing consumers' attitudes toward social media marketing". Journal of internet commerce, v. 10, n. 1, pp. 35-67.

https://doi.org/10.1080/15332861.2011.558456

Aqsa, Muhammad; Kartini, Dwi (2015). "Impact of online advertising on consumer attitudes and interests buy online (survey on students of internet users in Makassar)". International journal of scientific and technology research, v. 4 , n. 4, pp. 230-236.

https://www.ijstr.org/final-print/apr2015/Impact-Of-Online-Advertising-On-Consumer-Attitudes-And-Interests-BuyOnline-survey-On-Students-Of-Internet-Users-In-Makassar.pdf

Bailey, Kenneth D. (1987). Methods of social research. New York Free Press. ISBN: 9780029014509

Bauer, Hans H.; Reichardt, Tina; Barnes, Stuart J.; Neumann, Marcus M. (2005). “Driving consumer acceptance of mobile marketing: A theoretical framework and empirical study". Journal of electronic commerce research, v. 6, n. 3, pp. 181-192.

http://www.jecr.org/sites/default/files/06_3_p02.pdf

Brackett, Lana K.; Carr, Benjamin N. (2001). "Cyberspace advertising vs. other media: Consumer vs. mature student attitudes". Journal of advertising research, v. 41, n. 5, pp. 23-32.

https://doi.org/10.2501/JAR-41-5-23-32

Brown, Ruth E.; Jones, Valerie K.; Wang, Ming (2016). The new advertising: Branding, content, and consumer relationships in the data-driven social media era. Praeger. ISBN: 9781440833427

Caulfield, Darrel (2017). "6 second ads: Creativity in constraint". Wolfgang digital, October 20. https://www.wolfgangdigital.com/blog/6-second-ads-creativity-in-constraint

Cheng, Julian-Ming-Sung; Blankson, Charles; Wang, Edward-Shih-Tse; Chen, Lily-Shui-Lien (2009). "Consumer attitudes and interactive digital advertising". International journal of advertising, v. 28, n. 3, pp. 501-525.

https://doi.org/10.2501/S0265048709200710

Cheng, Zhi-Qi; Wu, Xiao; Liu, Yang; Hua, Xian-Sheng (2017). "Video eCommerce++: Toward large scale online video advertising". IEEE transactions on multimedia, v. 19, n. 6, pp. 1170-1183.

https://doi.org/10.1109/tmm.2016.2647386 
Chi, Clifford (2018). "13 amazing YouTube pre-roll ads that last just six seconds". HubSpot, June 15. https://blog.hubspot.com/marketing/best-six-second-pre-roll-ads-on-youtube

Chih-Chung, Chu; Chang, Chris; Lin, Lee-Wei-Chun; Yau-Nang (2012). "The effect of advertisement frequency on the advertisement attitude-The controlled effects of brand image and spokesperson's credibility". Procedia - Social and behavioral sciences, v. 57, pp. 352-359.

https://doi.org/10.1016/j.sbspro.2012.09.1197

Chu, Shu-Chuan; Kim, Yoojung (2011). "Determinants of consumer engagement in electronic word-of-mouth (eWOM) in social networking sites". International journal of advertising, v. 30, n. 1, pp. 47-75.

https://doi.org/10.2501/IJA-30-1-047-075

Cisco (2018). Cisco global cloud index: Forecast and methodology, 2016-2021 White paper. Cisco.

https://www.cisco.com/c/en/us/solutions/collateral/service-provider/global-cloud-index-gci/white-paper-c11-738085.html

Donato, Paul; Schiffman, Dan (2018). 6 second ads: Who, how \& when to use.

https://cdn.thearf.org/ARF_Knowledgebase/ARF\%20Audience\%20Measurement/AxS_2018/AxS18_How-to-Use-6s_Donato-Schiffman.pdf

Ducoffe, Robert H. (1995). "How consumers assess the value of advertising". Journal of current issues \& research in advertising, v. 17, n. 1, pp. 1-18.

https://doi.org/10.1080/10641734.1995.10505022

Ducoffe, Robert H. (1996). "Advertising value and advertising on the Web". Journal of advertising research, v. 36, n. 5, pp. 21-35.

Fisher, Lauren (2011). "Only 30\% of YouTube users skip pre-roll ads [Correction: $30 \%$ in fact watch the ads]". The next web, June 13.

https://thenextweb.com/socialmedia/2011/06/12/only-30-of-youtube-users-skip-pre-roll-ads

Fleck, Alissa (2018). "Marketers think the 6-second pre-roll spot is the best digital video ad format". Adweek, May 31. https://www.adweek.com/tv-video/marketers-think-the-6-second-pre-roll-spot-is-the-best-digital-video-ad-format

Gaber, Hazem-Rasheed; Wright, Len-Tiu (2014). "Fast-food advertising in social media. A case study on Facebook in Egypt". Journal of business and retail management research, v. 9, n. 1.

http://eprints.hud.ac.uk/id/eprint/23238

Google (2016). "Using bumper ads to boost brand reach". Think with Google.

https://www.thinkwithgoogle.com/products/bumper-ads

Gunawan, Lunardi (2015). "The impact of cosumers' attitude on online video advertising towards product branding". Ibuss management, v. 3, n. 2, pp. 413-422.

https://media.neliti.com/media/publications/184085-EN-the-impact-of-cosumers-attitude-on-onlin.pdf

Haghirian, Parissa; Dickinger, Astrid (2005). "Identifying success factors of mobile marketing". AP-Asia Pacific advances in consumer research, v. 6, eds. Yong-Uon Ha and Youjae Yi, Duluth, MN: Association for Consumer Research, pp. 28-29. https://www.acrwebsite.org/volumes/11857/volumes/ap06/AP-06

Haghirian, Parissa; Madlberger, Maria (2005). "Consumer attitude toward advertising via mobile devices. An empirical investigation among Austrian users". In: ECIS Proceedings. European conference on information systems.

https://aisel.aisnet.org/ecis2005/44

Hamedy, Saba (2016). "YouTube reaches more millenials than any TV network, research shows". Mashable, April 16. https://mashable.com/2016/04/15/youtube-report-growth-viewership

Haq, Zia ul (2009). "E-mail advertising: A study of consumer attitude toward e-mail advertising among Indian users". Journal of retail \& leisure property, v. 8, n. 3, pp. 207-223.

https://doi.org/10.1057/rlp.2009.10

IAB (2008). A Digital Video Advertising Overview, 14 p.

https://www.iab.com/wp-content/uploads/2015/09/dv-report-v3.pdf

IAB (2018a). IAB Internet advertising revenue report 2018. Full year results, $32 \mathrm{p}$.

https://www.iab.com/insights/iab-internet-advertising-revenue-report-2018-full-year-results

IAB (2018b). IAB annual report 2018, 17 p.

https://www.iab.com/wp-content/uploads/2019/08/IAB_Annual-Report_2018.pdf

IAB (2018c). Increased spending in original digital video programming and mobile video.

https://www.iab.com/insights/2018-video-ad-spend-study 
IAB (2018d). Video landscape report. IAB Digital Video Center of Excellence".

https://www.iab.com/wp-content/uploads/2018/05/IAB-Video-Landscape-Report-May-2018_-4th-Edition_Final.pdf

IPG Media Lab (2016). Does every second count? Understanding new video ad lengths.

https://www.ipglab.com/wp-content/uploads/2016/02/Ad-lengths-V6-FINAL_NEW-COLORS.pdf

Kelly, Louise; Kerr, Gayle; Drennan, Judy (2010). “Avoidance of advertising in social networking sites. The teenage prespective". Journal of interactive advertising, v. 10, n. 2, pp. 16-27.

https://doi.org/10.1080/15252019.2010.10722167

Kemp, Simon (2018). "Digital in 2018. World's internet users pass the 4 billion mark". We are social, January 30. https://wearesocial.com/blog/2018/01/global-digital-report-2018

Kirkpatrick, David (2017). "Study: 59\% of millennials only watch YouTube ads until they can skip". Marketing dive. https://www.marketingdive.com/news/study-59-of-millennials-only-watch-youtube-ads-until-they-can-skip/433597

Landau, Jeanne (2015). "Today's shorter attention spans scream for memorable response tools". Response, v. 23, n. 10, pp. 44-44.

Le, Tri-Dinh; Nguyen, Bao-Tran-Ho (2014). "Attitudes toward mobile advertising: A study of mobile web display and mobile app display advertising". Asian academy of management journal, v. 19, n. 2, pp. 87-103.

http://web.usm.my/aamj/19022014/Art\%205(87-104).pdf

Lee, Joonghwa; Lee, Mira (2011). "Factors influencing the intention to watch online video advertising". Cyberpsychology, behavior and social networking, v. 14, n. 10, pp. 619-624.

https://doi.org/10.1089/cyber.2009.0305

Li, Hao; Lo, Hui-Yi (2015). "Do you recognize its brand? The effectiveness of online in-stream video advertisements". Journal of advertising, v. 44, n. 3, pp. 208-218.

https://doi.org/10.1080/00913367.2014.956376

MacKenzie, Scott B.; Lutz, Richard J. (1989). "An empirical examination of the structural antecedents of attitude toward the ad in an advertising pretesting context". Journal of marketing, v. 53, n. 2, pp. 48-65.

https://doi.org/10.1177/002224298905300204

Marci, Carl (2018). "Leveraging 6-second ads in today's distracted world". The Advertising Research Foundation, 26 July. https://thearf.org/category/news-you-can-use/leveraging-6-second-ads-in-todays-distracted-world

Marvin, Ginny (2017). “Google launches ads measurement system for cross-device campaigns on YouTube, DoubleClick, GDN". Marketing land, May 26.

https://marketingland.com/google-ads-data-hub-beta-216059

Mehta, Abhilasha (2000). "Advertising attitudes and advertising effectiveness". Journal of advertising research, v. 40, n. 3, pp. 67-72.

https://doi.org/10.2501/jar-40-3-67-72

Milaković, Ivana; Mihić, Mirela (2015). “Predictors and outcome of attitudes towards advertising: Demographics, personal factors and WOM". Ekonomska misao i praksa, n. 2, pp. 409-432.

https://hrcak.srce.hr/149645

Moon, Jang-Ho (2014). "The impact of video quality and image size on the effectiveness of online video advertising on YouTube". International journal of contents, v. 10, n. 4, pp. 23-29.

https://doi.org/10.5392/IJoC.2014.10.4.023

O'Neil-Hart, Celie; Blumenstein, Howard (2016). "The latest video trends: Where your audience is watching". Think with Google.

https://www.thinkwithgoogle.com/consumer-insights/video-trends-where-audience-watching

Pashkevich, Max; Dorai-Raj, Sundar; Kellar, Melanie; Zigmond, Dan (2012). "Empowering online advertisements by empowering viewers with the right to choose: The relative effectiveness of skippable video advertisements on YouTube". Journal of advertising research, v. 52, n. 4, pp. 451-457.

https://doi.org/10.2501/JAR-52-4-451-457

Rick, Christophor (2011). "YouTube: Only 30\% of viewers actually skip skippable ads". Tubular insights, June 14. https://tubularinsights.com/true-view-youtube-touts-70-video-ads-actual-views

Saadeghvaziri, Faraz; Khodadad-Hosseini, Hamid (2011). “Mobile advertising: An investigation of factors creating positive attitude in Iranian customers". African journal of business management, v. 5, n. 2, pp. 394-404.

https://pdfs.semanticscholar.org/8e79/374d533e65e2a46ddf5680c302517292852b.pdf 
Schlosser, Ann E.; Shavitt, Sharon; Kanfer, Alaina (1999). "Survey of internet users' attitudes toward internet advertising". Journal of interactive marketing, v. 13, n. 3, pp. 34-54. https://doi.org/10.1002/(SICI)1520-6653(199922)13:3<34::AID-DIR3>3.0.CO;2-R

Shavitt, Sharon; Lowrey, Pamela; Haefner, James (1998). "Public attitudes toward advertising: More favorable than you might think". Journal of advertising research, v. 38, n. 4, pp. 7-22.

Shields, Mike (2016). "Ad measurement feuds on Facebook, YouTube hinge on code". The wall street journal, November 9. https://www.wsj.com/articles/ad-measurement-feuds-on-facebook-youtube-hinge-on-code-1478689200?tes/a=y

Shutterstock (2017). "Why you should be making 6-second video ads in 2018". The shutterstock blog, 10 October. https://www.shutterstock.com/blog/6-second-video-ads-2018-strategy

Sloane, Garett (2017). "Facebook gets brands ready for 6-second video ads". AdAge, July 26. https://adage.com/article/digital/facebook-brands-ready-6-video-ads/309929

Soh, Hyeonjin; Reid, Leonard N.; Whitehill-King, Karen (2009). "Measuring trust in advertising". Journal of advertising, v. 38, n. 2, pp. 83-104.

https://doi.org/10.2753/JOA0091-3367380206

Souiden, Nizar; Chtourou, Saber; Korai, Bernard (2017). “Consumer attitudes toward online advertising: The moderating role of personality". Journal of promotion management, v. 23, n. 2, pp. 207-227.

https://doi.org/10.1080/10496491.2016.1267676

Statista (2018a). "Number of monthly logged-in YouTube viewers worldwide as of May 2018 (in billions)". Statista. https://www.statista.com/statistics/859829/logged-in-youtube-viewers-worldwide

Statista (2018b). "Number of YouTube users worldwide from 2016 to 2021 (in billions)". Statista. https://www.statista.com/statistics/805656/number-youtube-viewers-worldwide

Statista (2018c). "Percentage of internet users in selected countries who watch online video content every day as of January 2018". Statista.

https://www.statista.com/statistics/319688/daily-online-video-usage

Tsang, Melody M.; Ho, Shu-chun; Liang, Ting-Peng (2004). “Consumer attitudes toward mobile advertising: An empirical study". International journal of electronic commerce, v. 8, n. 3, pp. 65-78.

https://doi.org/10.1080/10864415.2004.11044301

Turban, Efraim; Whiteside, Judy; King, David; Outland, Jon (2017). Introduction to electronic commerce and social commerce. Springer International Publishing. ISBN: 9783319500904

https://www.springer.com/gp/book/9783319500904

Verna, Paul; Clayton, Annalise; Creamer, Sean (2017). Digital video ad effectiveness. YouTube, Facebook, Instagram, Twitter, Snapchat and more. eMarketer.

https://s3.amazonaws.com/assets.pk4media.com/case-studies/Digital+Video+Ad+Effectivenes+2017.pdf

Wang, Guanyao; Zhuo, Li; Li, Jiafeng; Ren, Dongyue; Zhang, Jing (2018). “An efficient method of content-targeted online video advertising". Journal of visual communication and image representation, v. 50, pp. 40-48.

https://doi.org/10.1016/j.jvcir.2017.11.001

We are social (2018). Global digital report 2018.

https://digitalreport.wearesocial.com

Wolin, Lori D.; Korgaonkar, Pradeep (2003). "Web advertising: gender differences in beliefs, attitudes and behavior". Internet research, v. 13, n. 5, pp. 375-385.

https://doi.org/10.1108/10662240310501658

Xu, Haifeng; Li, Zhuolun (2014). "Advertising in new media: Exploring adoption of location-based mobile application advertising". In: Pacis 2014 Proceedings.

https://aisel.aisnet.org/pacis2014/146

Zanot, Eric J. (1984). "Public attitudes towards advertising". International journal of advertising, v. 3, n. 1, pp. 3-15. https://doi.org/10.1080/02650487.1984.11104995

Zernigah, Kiani-Irshad; Sohail, Kamran (2012). "Consumers' attitude towards viral marketing in Pakistan". Management \& marketing challenges for the knowledge society, v. 4, n. 7, pp. 645-662. 